\title{
STRATEGI PELATIHAN DAN \\ TIPE KEPRIBADIAN TERHADAP HASIL PENDIDIKAN DAN PELATIHAN (DIKLAT) PENGENALAN PEMANFAATAN TIK
}

\author{
Suryani Manurung dan Efendi Napitupulu \\ PPPPTK Medan dan PPs Universitas Negeri Medan \\ suryani.manurung@gmail.com
}

\begin{abstract}
Abstrak: Penelitian ini bertujuan untuk: mengetahui perbedaan hasil belajar diklat pengenalan dan pemanfaatan TIK dengan strategi pelatihan In service learning dan In service learning-On the job learning -In service learning; mengetahui perbedaan hasil belajar diklat pengenalan dan pemanfaatan TIK pada tipe kepribadian extrovert dengan introvert; dan mengetahui interaksi antara staregi pelatihan dan tipe kepribadian dalam mempengaruhi hasil belajar diklat pengenalan dan pemanfaatan TIK. Populasi adalah seluruh peserta diklat di Departemen Teknologi Informatika PPPPTK Bidang Bangunan dan Listrik. Sampel penelitian adalah peserta pendidikan dan pelatihan angkatan III, IV, V, VI periode II. Penelitian ini adalah quasi eksperimen dengan pengujian hipotesis menggunakan ANAVA dua jalur 2 x 2. Hasil penelitian menunjukkan bahwa: hasil belajar diklat pengenalan dan pemanfaatan TIK lebih tinggi daripada hasil belajar strategi pelatihan In Service Learning; tipe kepribadian introvert memperoleh hasil belajar diklat pengenalan dan pemanfaatan TIK lebih tinggi daripada hasil belajar tipe kerpibadian extrovert; terdapat interaksi antara strategi pelatihan dan tipe kepribadian dalam memberikan pengaruh terhadap hasil belajar diklat pengenalan dan pemanfaatan TIK
\end{abstract}

Kata Kunci: strategi pelatihan In service learning dan In service learning-On the job learning -In service learning, kepribadian extrovert dengan introvert

\begin{abstract}
This study aims to: determine differences in learning outcomes of the introduction and use of ICT training with training strategy In service In service learning and learning-on-the-job learning -In service learning; determine differences in learning outcomes of the introduction and use of ICT training on the introverted extrovert personality type; and the interaction between staregi training and personality type affects learning outcomes of education and training in the introduction and use of ICT. The population is all training participants in the Department of Information Technology and Electrical PPPPTK Building Sector. Samples were participants of the education and training of forces III, IV, V, VI II period. This study is a quasi experimental hypothesis testing using ANOVA two lanes $2 \times 2$. The results showed that: the introduction of learning outcomes and the use of ICT training is higher than the result of learning strategy training In Service Learning; introverted personality types to obtain recognition of learning outcomes and the use of ICT training is higher than extrovert kerpibadian types of learning outcomes; there is an interaction between training strategy and personality types in giving effect to the learning outcomes of the introduction and use of ICT training
\end{abstract}

Keywords: In service training strategy in service learning and learning-on-the-job learning in service learning, personality extrovert and introvert

\section{PENDAHULUAN}

Konsekuensi logis dari perubahan ini mengharuskan Kementerian Pendidikan nasional perlu menguatkan tata layanan sentralisasi melalui Unit Pelaksana Teknis (UPT). Hal ini sesuai dengan pendapat yang dikemukakan Slamet (2000, 28) bahwa Manajemen pendidikan berbasis sentralisasi yang dilakukan sebelum reformasi perlu diubah menjadi manajemen berbasis sekolah.
Kebijakan Kemendiknas terhadap penguatan UPT ini dituangkan dengan Keputusan Menteri Pendidikan Nasional Nomor 7 tahun 2007 tentang Organisasi dan Tata Kerja Lembaga Penjaminan Mutu Pendidikan (LPMP) dan Keputusan Menteri Pendidikan Nasional Nomor 8 tahun 2007 tentang Organisasi dan Tata Kerja Pusat Pengembangan Pemberdayaan Pendidikan dan Tenaga Kependidikan (PPPPTK). Keputusan Menteri Pendidikan 
Nasional tersebut pada dasarnya dibentuk untuk mengejawantahkan pengembangan Keputusan Menteri Pendidikan Nasional Nomor 16 tahun 2007 tanggal 4 Mei 2007 tentang standar Kualifikasi Akademik dan Standar Kompetensi Guru yang meliputi empat kompetensi guru yaitu Pedagogik, Kompetensi Kepribadian, Kompetensi Sosial dan Kompetensi Profesional.

Dalam rangka memenuhi tuntutan tersebut, maka seluruh kegiatan pelatihan harus mengacu pada ke empat standar kompetensi guru tersebut. Di samping itu wujud pemenuhan desentralisasi harus dilakukan baik secara langsung maupun tidak langsung melalui pemanfaatan media interaktif. Pelatihan bukan lagi hanya bersifat teoretis akademis akan tetapi penilaian dan atau evaluasi keberhasilan sebuah pelatihan harus menunjukkan outcome, baik manfaat untuk diri sendiri, sekolah maupun ketermanfaatan bagi masyarakat. Untuk mewujudkan hal tersebut PPPPTK Bidang Bangunan dan Listrik sebagai salah satu unit pelaksana teknis (UPT) kementerian pendidikan nasional telah melakukan redifinisi, reposisi dan reaktualisasi di antaranya pemusatan program pelatihan pada : (1) Diklat kompetensi yaitu pendidikan dan pelatihan untuk mencapai kompetensi program keahlian sesuai dengan standar industri. (2) Diklat Teknis yaitu pendidikan dan pelatihan untuk meningkatkan kemampuan pada program keahlian tertentu dalam rangka peningkatan proses belajar mengajar.

Salah satu pendidikan dan pelatihan Teknis yang dilaksanakan oleh PPPPTK Bidang Bangunan dan Listrik berdasarkan hasil analisis kebutuhan pelatihan atau Training Need Assement (TNA) pada Sekolah Menengah Kejuruan (SMK) adalah Diklat Pengenalan dan Pemanfaatan Teknologi Informasi dan Komunikasi. Diklat ini didasarkan pada kebutuhan guru dalam rangka meningkatkan profesinya melalui penggunaan TIK. Pengenalan dan Pemanfaatan TIK adalah salah satu program pendidikan dan pelatihan yang dilaksanakan bagi guru-guru SMK yang mencakup pengetahuan umum dan keterampilan pemanfaatan teknologi informasi dalam membantu pemelajaran guru di sekolah. Menurut Rosenberg (2001) dengan berkembangnya penggunaan TIK ada lima pergeseran dalam proses pembelajaran yaitu: (1) dari pelatihan ke penampilan, (2) dari ruang kelas ke di mana dan kapan saja, (3) dari kertas ke "on line" atau saluran, (4) fasilitas fisik ke fasilitas jaringan kerja, (5) dari waktu siklus ke waktu nyata.

$$
\text { Banyak faktor yang dapat }
$$
mempengaruhi proses pelatihan mata tataran pengenalan dan pemanfaatan TIK antara lain : Latar belakang peserta, lingkungan, fasilitas, pengetahuan dasar yang dimiliki seorang peserta, karakteristik kepribadian, lingkungan, fasilitas, dan keengganan untuk mengubah paradigma pengajaran. Namun demikian berbagai usaha dapat dilakukan untuk mengoptimalkan hasil belajar pendidikan dan pelatihan antara lain menciptakan kondisi pelatihan dengan study banding pada sekolahsekolah lain, agar peserta termotivasi untuk mengembangkan diri yang akhirnya diharapkan akan dapat meningkatkan hasil pelatihan.

Pada hakekatnya untuk mencapai optimalisasi hasil belajar diklat pengenalan dan pemanfaatan TIK tersebut memang dapat dilakukan dengan pelbagai cara. Strategi pelatihan adalah salah satu alternatif yang dapat ditempuh fasilitator dalam pengajaran mata tataran pengenalan dan pemanfaatan teknologi informasi. Dengan strategi pelatihan akan memungkinkan peserta dapat melakukan interaksi terhadap apa yang diajarkan. Peserta akan dapat memahami secara rinci langkahlangkah apa yang hendak dilakukan dalam pemanfaatan TIK terhadap pembelajaran di sekolah. Pendapat ini sesuai dengan yang dikemukan oleh Sloane dan Witney (1988) Bahwa "pendidikan dan Pelatihan mengacu pada simulasi pekerjaan yang sebenarnya. Metode ini dapat juga dilakukan di dalam kelas dengan seminar, kuliah dengan pemutaran film tentang pendidikan sumber daya manusia."

Tiga tahun terakhir, rata-rata nilai pengenalan dan pemanfaatan TIK mengalami penurunan yaitu persentase perolehan nilai A pada 2008, 2009 dan 2010 adalah 16,67\%, $13,89 \%$ dan $14,58 \%$ sedangkan masingmasing persentase perolehan nilai $\mathrm{B}$ dan $\mathrm{C}$ adalah 58,33\%, 50,00\%, 37,50\% dan 25,00 $\%, 30,56 \%$ dan $41,67 \%$. Diduga salah satu faktor penyebab terjadinya penurunan ini disebabkan oleh kegiatan proses pelatihan yang dilaksanakan selama ini kurang baik atau tidak memperhatikan nilai awal kepribadian peserta, penggunakan strategi pembelajaran yang tidak variatif, bahkan kemungkinan pelaksanaan proses pelatihan dilakukan secara pembelajaran satu arah bukan dengan pembelajaran dua arah, sehingga sasaran pencapaian kompetensi teknis tidak tercapai. 
Perkembangan Teknologi Informasi dan Komunikasi dan keberadaannya dalam sekolah di Indonesia menunjukkan jumlah yang sangat luar biasa. Data statistik APJII (2007) pengguna internet secara signifikan mengalami peningkatan mulai tahun 2001 dengan jumlah 4,2 juta dari 1,9 juta tahun 2000 , terdiri kategori perorangan 100.000 , perumahan dan keluarga 2.250.000, korporasi besar rata-rata 50 komputer dengan 1.000 pelanggan, korporasi menengah rata-rata 20 komputer dengan 5.000 pelanggan, UKM rata-rata 10 komputer sebanyak 20.000 pelanggan, sekolah dan perguruan tinggi 1,5 juta pengguna serta 2.500 warnet dengan rata-rata 100 pengguna. Dari data yang dipublikasikan oleh APJII dapat menjelaskan bahwa internet sebagai salah satu sumber belajar di sekolah telah mulai aktif di Indonesia sejak tahun 2001.

Dengan interaksi teknologi informasi dan komunikasi akan mengubah peranan guru, yang semula lebih banyak bertindak sebagai satu sumber belajar utama, menjadi pengelola kegiatan belajar yang memberi kesempatan dan bimbingan kepada anak didiknya untuk mencari dan menggunakan sumber belajar lain (Miarso Yusufhadi, 2005: 679). Dalam kaitan pengorganisasian Pendidikan dan Pelatihan Kompetensi Guru Teknologi Informasi dan Komunikasi, Miarso (2008) lebih lanjut mengemukakan bahwa standar kompetensi teknologi informasi dan komunikasi meliputi pembelajaran dengan komputer; pembelajaran berbantuan komputer; pembelajaran berbasis web; pembelajaran jarak jauh; pembelajaran melalui jaringan; pembelajaran dengan portal pengetahuan (knowledge portals) atau internet; dan pembelajaran dengan jaringan pengetahuan (knoweledge networks) atau e-learning. Dengan demikian dapat disimpulkan bahwa standar kompetensi yang harus dimiliki oleh guru TIK dalam rangka pencapaian kurikulum sekolah menengah kejuruan dapat digambarkan sebagai berikut yaitu (1) Kompetensi professional terdiri dari (a) Adaptif meliputi keterampilan komputer dan pengolah informasi. (b) Keahlian meliputi keahlian rekayasa perangkat lunak (RPL), Keahlian Multimedia, Keahlian Teknik Komputer dan Jaringan. (2) Kompetensi pedagogik (3) Kompetensi Sosial dan (4) Kompetensi Kepribadian.

Sikula Edward dalam Sumantri (2000:2) mengartikan pelatihan sebagai: "proses pendidikan jangka pendek yang menggunakan cara dan prosedur yang sistematis dan terorganisir. Para peserta pelatihan akan mempelajari pengetahuan dan keterampilan yang sifatnya praktis untuk tujuan tertentu. Amstrong (2000:198) mengemukan pendapatnya bahwa "Pelatihan adalah konsep terencana yang terintegrasi, yang cermat, yang dirancang untuk menghasilkan pemahaman yang diperlukan untuk meningkatkan kinerja pekerjaan. Sedangkan Mathis (2002: 5) menjelaskan istilah Pelatihan adalah "suatu proses dimana orang-orang mencapai kemampuan tertentu untuk membantu mencapai tujuan organisasi. Oleh karena itu, proses ini terikat dengan berbagai tujuan organisasi, pelatihan dapat dipandang secara sempit dan luas.

In Service Learning adalah pengajaran dan pembelajaran yang mengintegrasikan layanan secara penuh kepada peserta dengan instruksi dan refleksi untuk memperkaya pengalaman belajar, tanggungjawab peserta dan memperkuat kerjasama kelompok (National and Community Service, 2011). Secara lebih tegas Murphy \& Rasch (2010) menegaskan bahwa perubahan konseptual In Service Learning adalah sangat penting bagi peserta pelatihan untuk mencapai kebenaran yang mereka miliki, khususnya program layanan pembelajaran harus menyampaikan bahwa kesadaran dan dunia adalah berdampingan, dengan demikian realitas dibentuk oleh kesadaran manusia itu sendiri.

Sloane dan Witney (1988) lebih tegas memberikan pengertian bahwa In Service Learning dilakukan di luar tempat kerja pegawai. Pelatihan hanya mengacu pada simulasi pekerjaan yang sebenarnya. Tujuannya adalah untuk menghindarkan tekanan-tekanan yang mungkin mempengaruhi jalannya proses belajar. Metode ini dapat juga dilakukan di dalam kelas dengan seminar, kuliah dengan pemutaran film tentang pendidikan sumber daya manusia.

Hernandez (1996) berpendapat In Service Learning akan memberi hasil meningkatnya pemahaman yang lebih luas bagi peserta tentang apa yang dilaksanakan sebelumnya dalam pekerjaan sehari-hari dan ditunjukkan setelah menyelesaikan pelatihan.

Tujuan penelitian ini adalah untuk mengetahui dan mendeskripsikan untuk: (1) mengetahui perbedaan hasil belajar diklat pengenalan dan pemanfaatan Teknologi Informasi dan Komunikasi dengan strategi pelatihan In service learning dan In service learning-On the job learning -In service learning (In-On-In); (2) mengetahui perbedaan 
hasil belajar diklat pengenalan dan pemanfaatan Teknologi Informasi dan Komunikasi pada tipe kepribadian extrovert dengan tipe kepribadian introvert; (3) mengetahui interaksi antara staregi pelatihan dan tipe kepribadian dalam mempengaruhi hasil belajar diklat pengenalan dan pemanfaatan Teknologi Informasi dan Komunikasi.

\section{METODE PENELITIAN}

Penelitian ini akan dilaksanakan di Departemen Teknologi Informatika PPPPTK Bidang Bangunan dan Listrik. Populasi pada penelitian ini adalah seluruh peserta diklat yang mengikuti diklat pengenalan dan pemanfaatan TIK. Sampel penelitian ini adalah peserta pendidikan dan pelatihan angkatan III, IV, V, VI periode II. Penelitian ini tergolong ke dalam jenis penelitian eksperimen quasi, yang bertujuan untuk menguji pengaruh strategi pelatihan dan tipe kepribadian terhadap hasil belajar pendidikan dan pelatihan (diklat). Penelitian ini tergolong ke dalam jenis penelitian eksperimen quasi, yang bertujuan untuk menguji pengaruh strategi pelatihan dan tipe kepribadian terhadap hasil belajar pendidikan dan pelatihan (diklat).

Teknik pengumpulan data yang digunakan dalam penelitian ini menggunakan tes dan non tes. Untuk memperoleh data mengenai hasil belajar diklat digunakan hasil tes belajar yang dikembangkan sendiri oleh peneliti dengan team widyaiswara PPPPTK bidang Bangunan dan Listrik serta assessor TIK. Teknik pengumpulan data untuk tipe kepribadian digunakan tes psikologi dengan menggunakan Myers Briggs Type Indicator BMTI) yang digunakan di Pusat Pendidikan dan Pelatihan Pengawai (Pusdiklat) Kementerian Pendidikan Nasional.

Teknik analisis data yang dilakukan dalam penelitian ini adalah teknik statistik deskriptif dan inferensial. Teknik statistik deskriptif digunakan untuk mendeskripsikan data antara lain: nilai rata-rata (mean), modus, median, standard deviasi (sd) dan kecenderungan data. Teknik statistik inferensial digunakan untuk menguji hipotesis penelitian yaitu dengan menggunakan teknik analisis varians (ANAVA) dua jalur $(2 \times 2)$. Analisis data penelitian ini menggunakan program SPSS versi 11.0 for windows.

Sebelum analisis varians (ANAVA) dua jalur dilakukan, terlebih dahulu dilakukan uji persyaratan analisis yaitu uji normalitas dan homogenitas. Uji normalitas dilakukan dengan uji Lilliefors. Pengujiannya mempedomani nilai probabilitas yang diperoleh, yaitu apabila nilai probabilitas lebih besar atau sama dengan 0,05 ( $\mathrm{p} \geq 0,05$ ) maka data dinyatakan normal (Santoso, 2003b). Selanjutnya, untuk menguji homogenitas data digunakan Uji Barlett dan Uji Fisher. Apabila nilai signifikansi yang diperoleh lebih besar atau sama dengan $0,05(\mathrm{p} \geq 0,05)$ maka data dinyatakan homogen (Santoso, 2003a). Untuk mendapatkan nilai probabilitas dan signifikansi digunakan komputer program SPSS versi 11.0 for windows.

Adapun hipotesis statistik penelitian ini dirumuskan sebagai berikut :

a. Hipotesis Pertama

$\mathrm{H}_{0}: \mu \mathrm{A}_{1}=\mu \mathrm{A}_{2}$

$\mathrm{H}_{\mathrm{a}}: \mu \mathrm{A}_{1}>\mu \mathrm{A}_{2}$

b. Hipotesis Kedua

$\mathrm{H}_{0}: \mu \mathrm{B}_{1}=\mu \mathrm{B}_{2}$

$\mathrm{H}_{\mathrm{a}}: \mu \mathrm{B}_{1}>\mu \mathrm{B}_{2}$

c. Hipotesis Ketiga

$\mathrm{H}_{0}: \mathrm{A}><\mathrm{B}=0$

$\mathrm{H}_{\mathrm{a}}: \mathrm{B}><\mathrm{B} \neq 0$

Keterangan :

$\mu \mathrm{A}_{1}=$ Hasil belajar pendidikan dan pelatihan dengan strategi pelatihan In service learning

$\mu \mathrm{A}_{2}=$ Hasil belajar pendidikan dan pelatihan dengan strategi pelatihan In-On-In

$\mu \mathrm{B}_{1}=$ Hasil belajar pendidikan dan pelatihan dengan tipe kepribadian extrovert

$\mu \mathrm{B}_{2}=$ Hasil belajar pendidikan dan pelatihan dengan tipe kepribadian introvert

\section{HASIL DAN PEMBAHASAN \\ Hasil}

Dalam penelitian ini data yang diambil ada empat variabel yaitu data hasil belajar diklat pengenalan dan pemanfaatan TIK yang memiliki tipe kepribadian introvert dilatih dengan strategi pelatihan In-On-In $\left(\mathrm{X}_{1}\right)$, hasil belajar diklat pengenalan dan pemanfaatan TIK yang memiliki tipe kepribadian extrovert dilatih dengan strategi pelatihan In-On-In $\left(\mathrm{X}_{2}\right)$, hasil belajar diklat pengenalan dan pemanfaatan TIK yang memiliki tipe kepribadian introvert dilatih dengan strategi pelatihan In Service Learning $\left(\mathrm{X}_{3}\right)$, hasil belajar diklat pengenalan dan pemanfaatan TIK yang memiliki tipe kepribadian extrovert dilatih dengan sttategi pelatihan In Sevice Learing $\left(\mathrm{X}_{4}\right)$. Berdasarkan pengolahan data akan diuraikan berturut-tuut tentang deskripsi data, masing-masing variabel penelitian, pengujian persyaratan analisis dan pengajuan hipotesis. 
Tabel 1. Ringkasan Deskripsi Data Variabel

\begin{tabular}{|l|r|r|r|r|}
\hline & \multicolumn{1}{|c|}{ X1 } & \multicolumn{1}{|c|}{ X2 } & \multicolumn{1}{c|}{ X3 } \\
\hline $\mathrm{N}$ & 11 & 12 & 10 & 14 \\
Mean & 42,09 & 32,92 & 33,30 & 2,0327 \\
Median & 41,33 & 32,17 & 32,50 & 29,90 \\
Mode & 42,75 & 30,30 & 32,50 & 30,00 \\
Std. Deviation & 1,9212 & 2,1515 & 2,5841 & 2,0327 \\
Variance & 3,69 & 3,12 & 6,68 & 4,13 \\
Range & 6 & 6 & 9 & 7 \\
Minimum & 45 & 36 & 37 & 33 \\
Maximum & 39 & 30 & 28 & 26 \\
Sum & 463 & 395 & 333 & 422 \\
\hline
\end{tabular}

Berdasarkan data skor tes hasil belajar diklat pengenalan dan pemanfaatan TIK, maka dapat dirangkum banyak data, skor total, jumlah kuadrat dan rata-rata untuk setiap sel, baris dan kolom.

Tabel 2. Tabulasi Jumlah Desain Penelitian Anava 2 x 2 untuk n tidak sama

\begin{tabular}{|c|c|c|c|}
\hline $\begin{array}{l}\text { Tipe } \\
\text { Kepribadian }\end{array}$ & $\begin{array}{l}\text { In-On-In } \\
\left(\mathrm{A}_{1}\right)\end{array}$ & $\begin{array}{l}\text { In Service Learning } \\
\qquad\left(\mathrm{A}_{2}\right)\end{array}$ & Total \\
\hline $\begin{array}{l}\text { Introvert } \\
\quad\left(\mathrm{B}_{1}\right)\end{array}$ & $\begin{array}{l}\sum X_{11}=463 \\
X_{11}=42,09 \\
n_{11}=11\end{array}$ & $\begin{array}{l}\sum X_{21}=333 \\
X_{21}=33,30 \\
n_{21}=10\end{array}$ & $\begin{array}{l}\sum\left(X_{11}+X_{21}\right)=796 \\
X(11+21)=37,90 \\
n\left({ }_{11}+21\right)=21\end{array}$ \\
\hline $\begin{array}{l}\text { Extrovert } \\
\qquad\left(\mathrm{B}_{2}\right)\end{array}$ & $\begin{array}{l}\sum \mathrm{X}_{12}=395 \\
\mathrm{X}_{12}=32,92 \\
\mathrm{n}_{12}=12\end{array}$ & $\begin{array}{l}\sum_{22}=422 \\
X_{22}=30,14 \\
n_{22}=14\end{array}$ & $\begin{array}{l}\sum\left(\mathrm{X}_{12}+\mathrm{X}_{22}\right)=817 \\
\mathrm{X}(12+22)=31,42 \\
\mathrm{n}(12+22)=26\end{array}$ \\
\hline Total & $\begin{array}{l}\sum_{(11}\left(X_{11}+X_{12}\right)=858 \\
Z_{(11+12)}=37,30 \\
n_{(11+12)}=23\end{array}$ & $\begin{array}{l}\sum_{\left(X_{21}+X_{22}\right)=755} \\
\left.X_{(21}+22\right)=31,46 \\
\left.n_{(21}+22\right)=24\end{array}$ & $\begin{array}{l}\sum X=1613 \\
X=34,32 \\
n=47\end{array}$ \\
\hline
\end{tabular}

Keterangan :

$\mathrm{X}_{11}=$ Jumlah keseluruhan skor petatar yang dilatih dengan strategi In-On-In yang memiliki tipe kepribadian Introvert

$\mathrm{X}_{12}=$ Jumlah keseluruhan skor petatar yang dilatih dengan strategi In-On-In yang memiliki tipe kepribadian Extrovert

$\mathrm{X}_{21}=$ Jumlah keseluruhan skor petatar yang dilatih dengan strategi In Service Learning yang memiliki tipe kepribadian Introvert

$\mathrm{X}_{22}=$ Jumlah keseluruhan skor petatar yang dilatih dengan strategi In Service Learning yang memiliki tipe kepribadian Extrovert

$X_{11}=$ Rata-rata skor untuk petatar yang dilatih dengan strategi In-On-In yang memiliki tipe kepribadian Introvert
$X_{12}=$ Rata-rata skor untuk petatar yang dilatih dengan strategi In-On-In yang memiliki tipe kepribadian Extrovert

$X_{21}=$ Rata-rata skor untuk petatar yang dilatih dengan strategi In Service Learning yang memiliki tipe kepribadian Introvert

$X_{22}=$ Rata-rata skor untuk petatar yang dilatih dengan strategi In Service Learning yang memiliki tipe kepribadian Extrovert

$=$ Rata-rata skor untuk keseluruhan petatar

$\mathrm{n}_{11}=$ Jumlah petatar yang dilatih dengan strategi In-On-In yang memiliki tipe kepribadian Introvert

$\mathrm{n}_{12}=$ Jumlah petatar yang dilatih dengan strategi In-On-In yang memiliki tipe kepribadian Extrovert 
$\mathrm{n}_{21}=$ Jumlah petatar yang dilatih dengan strategi In Service Learning yang memiliki tipe kepribadian Introvert

$\mathrm{n}_{22}=$ Jumlah petatar yang dilatih dengan strategi In Service Learning yang memiliki tipe kepribadian Extrovert
Rangkuman hasil perhitungan Anava dengan faktorial 2 x 2 untuk pengujian hipotesis penelitian ini ditunjukkan dalam tabel 3 berikut ini.

Tabel 3. Pengujian Hipotesis Pengaruh Strategi Pelatihan dan Tipe Kepribadian Terhadap Hasil Belajar Diklat Pengenalan dan Pemanfaaatan TIK

\begin{tabular}{|c|c|c|c|c|c|}
\hline Sumber Variansi & JK & $\mathrm{dk}$ & RJK & $\mathrm{F}$ & Ftabel $(\alpha=0,05)$ \\
\hline Baris (A) & 488,06 & 1 & 488,06 & 104,08 & \multirow[t]{5}{*}{4,072} \\
\hline Kolom (B) & 401,38 & 1 & 401,38 & 85,60 & \\
\hline Interaksi (AB) & 53,131 & 1 & 53,131 & 11,33 & \\
\hline Galat & 201,64 & 43 & 4,69 & & \\
\hline Total & 1144,21 & 46 & & & \\
\hline
\end{tabular}

Pengaruh Strategi Pelatihan In-On-In dan In Service Learning Terhadap Hasil Belajar Diklat Pengenalan dan Pemanfaatan Internet

Hipotesis statistik yang diuji adalah :

$\mathrm{H}_{0} \quad: \mu_{\mathrm{A} 1}=\mu_{\mathrm{A} 2}$

$\mathrm{H}_{\mathrm{a}} \quad: \mu_{\mathrm{A} 1}>\mu_{\mathrm{A} 2}$

Berdasarkan rangkuman hasil

perhitungan pada tabel 3. diatas, dapat dilihat bahwa harga nilai $F_{\text {hitung }}=104,08$. Nilai presentil distribusi $\mathrm{F}$ dengan $\mathrm{dk}(1,43)$ pada taraf $\alpha=0,05$ adalah 4,072. Hasil ini menunjukkan bahwa $\mathrm{F}_{\text {hitung }}=104,08>\mathrm{F}_{\text {tabel }}=$ 4,072, sehingga keputusan menolak $\mathrm{H}_{0}$ pada taraf signifikansi $\alpha=0,05$. Hipotesis penelitian yang menyatakan "Kelompok petatar yang dilatih dengan strategi pelatihan In-In-On akan memperoleh hasil belajar diklat pengenalan dan pemanfaatan TIK yang lebih tinggi daripada kelompok petatar yang dilatih dengan strategi pelatihan In Service Learning" teruji kebenarannya.

Pengaruh Tipe Kepribadian Introvert dan Extrovert Terhadap Hasil Belajar Diklat Pengenalan dan Pemanfaatan Internet

Hipotesis statistik yang diuji adalah :

$\begin{array}{ll}\mathrm{H}_{0} & : \mu_{\mathrm{B} 1}=\mu_{\mathrm{B} 2} \\ \mathrm{H}_{\mathrm{a}} & : \mu_{\mathrm{B} 1}>\mu_{\mathrm{B} 2}\end{array}$

Berdasarkan rangkuman hasil perhitungan pada tabel 3. diatas, dapat dilihat bahwa harga nilai $F_{\text {hitung }}=85,60$. Nilai presentil distribusi $\mathrm{F}$ dengan $\mathrm{dk}(1,43)$ pada taraf $\alpha=$ 0,05 adalah 4,072. Hasil ini menunjukkan bahwa $F_{\text {hitung }}=85,60>F_{\text {tabel }}=4,072$, sehingga keputusan menolak $\mathrm{H}_{0}$ pada taraf signifikansi $\alpha$ $=0,05$. Hipotesis penelitian yang menyatakan "Kelompok petatar yang memiliki tipe kepribadian introvert akan memperoleh hasil belajar diklat pengenalan dan pemanfaatan TIK yang lebih tinggi daripada kelompok petatar yang memiliki tipe kepribadian eztrovert" teruji kebenarannya.

Interaksi Antara Strategi Pelatihan dan Tipe Kepribadian Terhadap Hasil Belajar Diklat Pengenalan dan Pemanfaatan Internet

Hipotesis statistik yang diuji adalah :

$\mathrm{H}_{0} \quad: \mathrm{A} . \mathrm{B}=0$

$\mathrm{H}_{\mathrm{a}} \quad: \mathrm{A} . \mathrm{B} \neq 0$

Berdasarkan rangkuman hasil perhitungan pada tabel 3. diatas, dapat dilihat bahwa harga nilai $F_{\text {hitung }}=11,33$. Nilai presentil distribusi $\mathrm{F}$ dengan $\mathrm{dk}(1,43)$ pada taraf $\alpha=$ 0,05 adalah 4,072. Hasil ini menunjukkan bahwa $F_{\text {hitung }}=11,33>\mathrm{F}_{\text {tabel }}=4,072$, sehingga keputusan menolak $\mathrm{H}_{0}$ pada taraf signifikansi $\alpha$ $=0,05$. Hipotesis penelitian yang menyatakan "Terdapat interaksi antara strategi pelatihan dan tipe kepribadian dalam memberikan pengaruh terhadap hasil belajar diklat pengenalan dan pemanfaatan TIK" teruji kebenarannya.

Dari pengujian hipotesis ketiga menyatakan bahwa terdapat interaksi antara strategi pelatihan dan tipe kepribadian dalam memberikan pengaruh terhadap hasil belajar diklat pengenalan dan pemanfaatan TIK, oleh karenanya diperlukan pengujian lanjutan untuk mengetahui skor rata-rata mana yang memberikan pengaruh terhadap peningkatan hasil belajar diklat pengenalan dan pemanfaatan TIK. Berdasarkan jumlah sampel yang tidak sama pada setiap sel pada tabel anava, maka pengujian lanjutan dilakukan dengan menggunakan uji Scheffe. Dari hasil perhitungan yang dilakukan diperoleh perbandingan $F_{\text {hitung }}$ dan $F_{\text {tabel }}$ sebagaimana dalam tabel 4. dibawah ini. 
Tabel 4. Rangkuman Hasil Pengujian Hipotesis Terhadap Interaksi

\begin{tabular}{|c|c|c|}
\hline Skor Kelompok yang dibandingkan & $F_{\text {hitung }}$ & $F_{\text {tabel }}$ \\
\hline$\mu \mathrm{A}_{1} \mathrm{~B}_{1}$ dengan $\mu \mathrm{A}_{2} \mathrm{~B}_{1-}$ & 9,29 & 2,85 \\
\hline$\mu \mathrm{A}_{1} \mathrm{~B}_{1}$ dengan $\mu \mathrm{A}_{1} \mathrm{~B}_{2-}$ & 10,15 & 2,85 \\
\hline$\mu \mathrm{A}_{1} \mathrm{~B}_{1}$ dengan $\mu \mathrm{A}_{2} \mathrm{~B}_{2-}$ & 13,69 & 2,85 \\
\hline$\mu \mathrm{A}_{1} \mathrm{~B}_{2}$ dengan $\mu \mathrm{A}_{2} \mathrm{~B}_{1-}$ & 0,41 & 2,85 \\
\hline$\mu \mathrm{A}_{1} \mathrm{~B}_{2}$ dengan $\mu \mathrm{A}_{2} \mathrm{~B}_{2-}$ & 3,25 & 2,85 \\
\hline$\mu \mathrm{A}_{2} \mathrm{~B}_{1}$ dengan $\mu \mathrm{A}_{2} \mathrm{~B}_{2-}$ & 3,52 & 2,85 \\
\hline
\end{tabular}

Dari hasil perhitungan uji Scheffe ini dapat disimpulkan bahwa : (a) Petatar yang memiliki tipe kepribadian Introvert akan memperoleh hasil belajar diklat pengenalan dan pemanfaatan TIK yang lebih tinggi bila dilatih dengan strategi pelatihan In-On-In daripada petatar yang dilatih dengan strategi in service learning, yang ditunjukkan oleh $\mathrm{F}_{\text {hitung }}=9,29>\mathrm{F}_{\text {tabel }}=$ 2,85 pada taraf signifikansi $\alpha=0,05$; (b) Petatar yang dilatih dengan strategi In-In-On akan memperoleh hasil belajar diklat pengenalan dan pemanfaatan TIK yang lebih tinggi bagi petatar yang memiliki tipe kepribadian Introvert daripada petatar yang memiliki tipe kepribadian Extrovert, yang ditunjukkan oleh $\mathrm{F}_{\text {hitung }}=10,15>\mathrm{F}_{\text {tabel }}=2,85$ pada taraf signifikansi $\alpha=0,05$; (c) Hasil belajar diklat pengenalan dan pemanfaatan TIK yang dilatih dengan strategi pelatihan $I n-I n-O n$ yang memiliki tipe kepribadian Introvert lebih tinggi daripada petatar dilatih dengan strategi In Service Learning yang memiliki tipe kepribadian Extrovert, yang ditunjukkan oleh $\mathrm{F}_{\text {hitung }}=13,69>\mathrm{F}_{\text {tabel }}=2,85$ pada taraf signifikansi $\alpha=0,05$; (d) Hasil belajar diklat pengenalan dan pemanfaatan TIK yang dilatih dengan strategi pelatihan In-In-On yang memiliki tipe kepribadian Extrovert berbeda dengan hasil belajar diklat petatar yang dilatih dengan strategi In Service Learning yang memiliki tipe kepribadian Introvert, yang ditunjukkan oleh $\mathrm{F}_{\text {hitung }}=0,41<\mathrm{F}_{\text {tabel }}=2,85$ pada taraf signifikansi $\alpha=0,05$; (e) Petatar yang dilatih dengan strategi $I n-I n-O n$ yang memiliki tipe kepribadian Extrovert akan memperoleh hasil belajar diklat pengenalan dan pemanfaatan TIK yang lebih tinggi daripada petatar yang dilatih dengan strategi pelatihan In Service Learning yang memiliki tipe kepribadian Extorvert, yang ditunjukkan oleh $\mathrm{F}_{\text {hitung }}=3,25>$ $\mathrm{F}_{\text {tabel }}=2,85$ pada taraf signifikansi $\alpha=0,05$; (f) Petatar yang dilatih dengan strategi In Service Learning yang memiliki tipe kepribadian Introvert akan memperoleh hasil belajar diklat pengenalan dan pemanfaatan TIK yang lebih tinggi daripada petatar yang dilatih dengan strategi pelatihan In Service Learning yang memiliki tipe kepribadian Extorvert, yang ditunjukkan oleh $\mathrm{F}_{\text {hitung }}=3,52>\mathrm{F}_{\text {tabel }}=2,85$ pada taraf signifikansi $\alpha=0,05$;

Untuk melihat dengan jelas model Anava yang menunjukkan interaksi antara strategi pelatihan dan tipe kepribadian, dapat dilihat pada grafik estimasi dibawah ini.

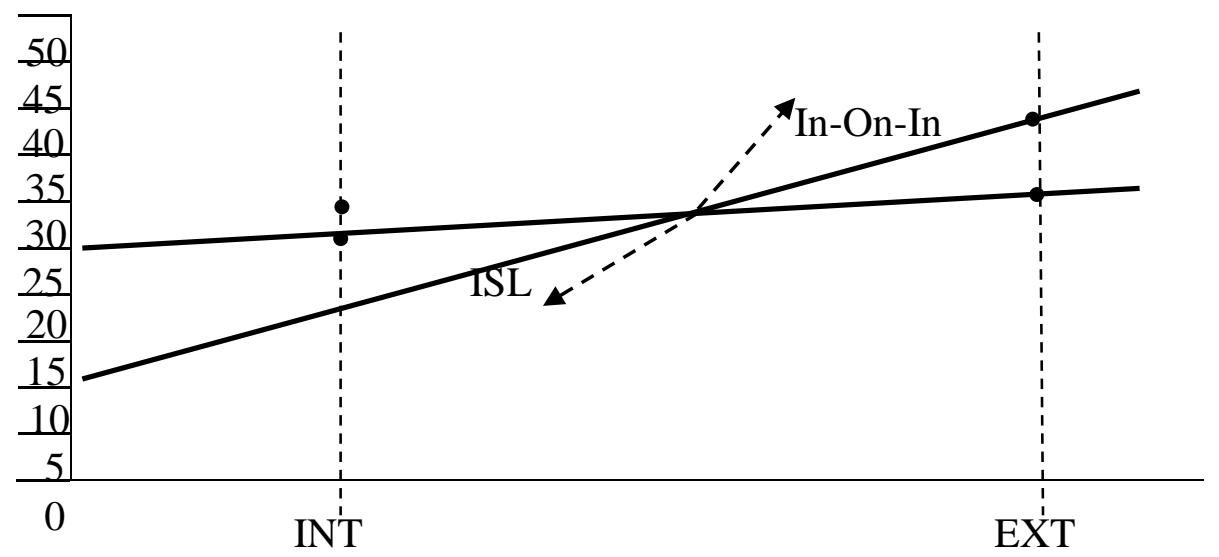

Gambar 1. Model Interaksi Strategi Pelatihan dan Tipe Kepribadian Terhadap Hasil Belajar Diklat Pengenalan dan Pemanfaatan TIK 


\section{Pembahasan}

Berdasarkan hasil penelitian yang diperoleh melalui pengujian hipotesis, maka interpretasi atas hasil penelitian ini secara spesifik dapat dipaparkan sebagai berikut:

Strategi Pelatihan In-In-On dan In Service Learning Terhadap Hasil Belajar Diklat Pengenalan dan Pemanfaatan TIK.

Berdasarkan hasil penelitian yang dilakukan, bahwa untuk hasil belajar diklat pengenalan dan pemanfaatan TIK yang dilatihkan dengan menggunakan strategi pelatihan In-In-On memperoleh rata-rata 37,30 sedangkan untuk petatar yang dilatih dengan strategi In Service Learning memperoleh ratarata 34,32. Demikian juga pengujian kebenaran atas hipotesis petatar yang dilatih dengan strategi pelatihan In-In-On akan memperoleh hasil belajar diklat pengenalan dan pemanfaatan TIK yang lebih tinggi daripada kelompok petatar yang dilatih dengan strategi pelatihan In Service Learning telah teruji kebenarannya dalam penelitian ini.

Berbeda dengan strategi pelatihan In Service Learning, bentuk strategi pelatihan ini merupakan bentuk kegiatan instruksional dengan menggunakan penatar atau widyaiswara sebagai satu-satunya sumber belajar, demikian juga untuk mengembangkan psikomotorik petatar melalui praktek, widyaiswara juga lebih banyak berperan untuk menggali sumber dan atau mengarahkan peserta hanya sekitar wilayah tempat pelatihan. Secara umum bentuk pelatihan dengan strategi pelatihan In Service Learning lebih didominasi teoritis, karena keterbatasan data penatar dan petatar untuk mengimplementasikan praktek ke dalam unjuk kerja.

Tipe Kepribadian Introvert dan Extrovert Terhadap Hasil Belajar Diklat Pengenalan dan Pemanfaatan TIK.

Berdasarkan hasil penelitian yang dilakukan, bahwa hasil belajar diklat pengenalan dan pemanfaatan TIK bagi petatar yang memiliki tipe kepribadian introvert memperoleh rata-rata 37,90 sedangkan untuk petatar yang memiliki tipe kepribadian extrovert memperoleh rata-rata 31,42. Demikian juga pengujian kebenaran atas hipotesis bahwa petatar yang memiliki tipe kepribadian introvert akan memperoleh hasil belajar diklat pengenalan dan pemanfaatan TIK yang lebih tinggi daripada kelompok petatar yang memiliki tipe kepribadian eztrovert" telah teruji kebenarannya dalam penelitian ini.
Kebenaran dalam penelitian ini tentang kecenderungan bahwa tipe kepribadian introvert lebih menguasai pengenalan dan pemanfaatan TIK adalah sesuai sifat yang dimiliki oleh tipe introvert lebih dekat dengan karakteristik dan substansi proses TIK itu sendiri yang membutuhkan keseriusan dalam mendapat hasil yang baik, sebagaimana Dabbagh \& Ritland (2005: 39) mengemukakan bahwa pebelajar yang online harus menguasai keterampilan belajar mandiri (self directed learning) atau didukung suatu latihan untuk memperoleh keterampilan seperti itu sehingga mereka dapat dengan aktif terlibat dalam proses pembelajaran yang diarahkan pada mereka, hal ini menggambarkan bahwa proses pembelajaran tentang TIK, lebih cenderung dalam proses mandiri, proses interaksi lingkungan disini lebih diarahkan pada lingkungan maya. Kondisi ini sangat relevan dengan sifat-sifat yang dimiliki oleh tipe kepribadian introvert dibanding dengan tipe kepribadian extrovert. Sifat-sifat introvert dimaksud adalah kecenderungan untuk berfokus pada dunia di dalam diri sendiri, orang-orang introvert cenderung tenang, damai dan hati-hati dan tidak tertarik pada interaksi sosial langsung. Mereka menyukai aktivitas yang bisa mereka lakukan sendiri atau dengan salah satu teman dekat yang lain, kegiatan seperti membaca, menulis, berpikir, dan menciptakan.

Terdapat Interaksi Antara Strategi Pelatihan dan Tipe Kepribadian Terhadap Hasil Belajar Diklat Pengenalan dan Pemanfaatan Internet. Berdasarkan hasil penelitian yang dilakukan, bahwa hasil belajar diklat pengenalan dan pemanfaatan TIK bagi petatar dipengaruhi oleh strategi pelatihan dan tipe kepribadian. Demikian juga pengujian kebenaran atas hipotesis bahwa Terdapat interaksi antara strategi pelatihan dan tipe kepribadian dalam memberikan pengaruh terhadap hasil belajar diklat pengenalan dan pemanfaatan TIK, telah teruji kebenarannya dalam penelitian ini. Hal ini bermakna bahwa hasil belajar diklat pengenalan dan pemanfaatan TIK bagi petatar di PPPPTK Bidang Bangunan dan Listrik Medan dipengaruhi oleh strategi pelatihan dan tipe kepribadian petatar. Dalam penelitian ini ditunjukkan oleh anava 2 jalur yang secara jelas menunjukkan terdapatnya interaksi antara strategi pelatihan dan tipe kepribadian dalam mempengaruhi hasil belajar diklat pengenalan dan pemanfaatan TIK.

Untuk mengetahui interaksi tersebut, telah dilakukan pengujian lanjutan dengan uji 
scheffe pada masing-masing sel dan antar sel. Adapun interpretasi dari masing-masing interaksi dikemukakan sebagai berikut: Petatar yang memiliki tipe kepribadian Introvert akan memperoleh hasil belajar diklat pengenalan dan pemanfaatan TIK yang lebih tinggi bila dilatih dengan strategi pelatihan $I n$ On-In daripada petatar yang dilatih dengan strategi in service learning. Hal ini sangat bisa dipahami sebagaimana pada bagian sebelumnya, bahwa tipe kepribadian introvert yang cenderung dalam melakukan proses belajar secara mandiri, sangat berkesempatan untuk memanfaatkan potensi dirinya pada saat dilakukannya pembelajaran atau pelatihan On The Job Learning (OJT). Tipe kepribadian Introvert akan lebih terfokus dalam menyelesaikan tugas unjuk kerja yang diberikan penatar atau widyaiswara dengan melakukan interaksi pada jaringan internet yang merupakan sumber utama mata tataran pengenalan dan pemanfaatan TIK. (b) Petatar yang dilatih dengan strategi In-In-On akan memperoleh hasil belajar diklat pengenalan dan pemanfaatan TIK yang lebih tinggi bagi petatar yang memiliki tipe kepribadian Introvert daripada petatar yang memiliki tipe kepribadian Extrovert. Hal ini dapat dipahami karena kondisi pelatihan dengan strategi In-On-In bagi tipe kepribadian Introvert akan memberikan kesempatan dalam melakukan pelatihan yang diolah dan diatur oleh diri sendiri tanpa pengaruh orang lain, sehingga potensi dirinya akan muncul lebih maksimal karena tidak lagi dipengaruhi oleh orang lain maupun penatarnya sendiri. Sedangkan bagi tipe Extrovert, kondisi ini akan dapat mendorong tidak terselesaikannya tugas unjuk kerja yang diberikan karena sebagaimana sifat tipe extrovert akan mudah dipengaruhi lingkungan sendiri. (c) Hasil belajar diklat pengenalan dan pemanfaatan TIK yang dilatih dengan strategi pelatihan In-In-On yang memiliki tipe kepribadian Introvert lebih tinggi daripada petatar dilatih dengan strategi In Service Learning yang memiliki tipe kepribadian Extrovert. Hal ini dapat dipahami karena strategi pelatihan $I n$-On-In memiliki konsep untuk memberikan kesempatan secara mandiri bagi peserta untuk dapat mengaplikasikan teoriteori yang dipelajari pada tugas unjuk kerja yang diberikan, petatar diberikan kesempatan untuk bertindak, belajar dan berkreasi yang dipandu oleh dirinya sendiri. Petatar hanya menjadi konsultan dan sumber refrensi bagi petatar di tempat OJT. Sedangkan diklat dengan strategi pelatihan In Service Learning yang memiliki tipe kepribadian Extrovert, penatar atau widyaiswara lebih mendominasi arah dan tujuan pelatihan, walaupun sebenarnya kondisi ini sangat baik pada tipe kepribadian extrovert, namun karena jumlah dan sarana yang diberikan pada pelatihan terbatas, maka jaringan sosial langsung yang terbentuk oleh tipe extrovert juga terbatas, selain itu bahwa setiap peserta juga memiliki kemampuan yang masih terbatas untuk dapat berbagi diantara mereka, sehingga pada akhirnya tujuan psikologis jaringan sosial mereka akan berubah arah dari dukungan terhadap pelatihan mereka. (d) Hasil belajar diklat pengenalan dan pemanfaatan TIK yang dilatih dengan strategi pelatihan In-In-On yang memiliki tipe kepribadian Extrovert berbeda dengan hasil belajar diklat petatar yang dilatih dengan strategi In Service Learning yang memiliki tipe kepribadian Introvert. Pada uji scheffe diatas menunjukkan bahwa perbedaan ini tidak signifikan yang ditunjukkan oleh $\mathrm{F}_{\text {hitung }}=0,41<$ $\mathrm{F}_{\text {tabel }}=2,85$ pada taraf signifikansi $\alpha=0,05$. Hasil ini dapat dipahami karena petatar yang memiliki tipe kepribadian extrovert lebih cenderung berinteraksi langsung terhadap masalah apa saja yang menjadi pokok pembicaraan pada saat berada dalam suatu jaringan sosial. Dengan pelatihan yang dilakukan dengan On The Job Learning ditempat tugas masing-masing, akan membuat tipe extrovert tidak fokus pada masalah tugas unjuk kerja yang sedang dilakukan. Jelas bahwa ruang jaringan komunitas disekolah akan membuat tipe ekstrovert masuk dalam banyak arah komunikasi diluar tugas unjuk kerja yang sedang dilaksanakan, yang dapat menimbulkan tidak berkembangkan peningkatan kemampuan hasil belajar diklatnya. Demikikan juga tipe kepribadian Introvert yang dilatih dengan strategi pelatihan In Service Learning akan mengalami kesulitan yang sangat berarti bila diarahkan, dan dibatasi pada hal-hal tertentu. (e) Petatar yang dilatih dengan strategi In-In-On yang memiliki tipe kepribadian Extrovert akan memperoleh hasil belajar diklat pengenalan dan pemanfaatan TIK yang lebih tinggi daripada petatar yang dilatih dengan strategi pelatihan In Service Learning yang memiliki tipe kepribadian Extorvert. Hasil penelitian ini dapat dipahami sebagaimana sifat dan karakteristik ekstrovert adalah mampu mengembangkan dirinya berdasarkan kondisi dan luasnya lingkungan yang mendukung dirinya. Lingkungan tempat pelatihan di PPPPTK 
Bidang Bangunan dan Listrik Medan secara nyata merupakan lingkungan yang terbatas, baik dari sarana, jumlah maupun dukungan data untuk tugas unjuk kerja. Oleh karena itu bilamana tipe kepribadian extrovert mampu mengelola lingkungan sekolah sebagai sumber belajarnya, tipe kepribadian extrovert akan dapat meningkatkan kemampuan hasil belajar pengenalan dan pemanfaat TIK, karena komunitas jaringan sosial dukungan yang diperoleh dapat berasal dari kepala sekolah, guru, masyarakat dan siswa-siswa yang memiliki kemampuan TIK. (f) Petatar yang dilatih dengan strategi In Service Learning yang memiliki tipe kepribadian Introvert akan memperoleh hasil belajar diklat pengenalan dan pemanfaatan TIK yang lebih tinggi daripada petatar yang dilatih dengan strategi pelatihan In Service Learning yang memiliki tipe kepribadian Extorvert. Hasil penelitian ini menunjukkan bahwa peranan sarana jaringan secara nyata mendukung hasil belajar diklat pengenalan dan pemanfaatan TIK bagi tipe kepribadian Introvert. Dengan lingkungan dan data yang terbatas pada strategi pelatihan In Service Learning, tipe Introvert dapat lebih meningkatkan kemampuan hasil belajarnya dibandingkan dengan tipe kepribadian Extrovert. Hal dapat dipahami bahwa kondisi yang terbatas sangat sulit bagi tipe kepribadian extrovert, keterbatasan dimaksud antara lain berupa kemampuan kompetensi anggota jaringan sosial tipe kepribadian extrovert terhadap pengenalan dan pemanfaatan TIK belum memadai sehingga mereka tidak dapat melakukan interaksi diskusi pelatihan yang maksimal. Interaksi terhadap penatar atau widyaiswara juga sangat terbatas, dan juga lingkungan PPPPTK bidang Bangunan dan Listrik yang jauh dari sumber-sumber refrensi nyata untuk diklat pengenalan dan pemanfaatan TIK. Dengan demikian tipe kepribadian Introvert lebih cenderung menguasai diklat pengenalan dan pemanfaatan TIK yang dilatih dengan strategi In Service Learning.'

\section{PENUTUP}

\section{Simpulan}

Pertama, Strategi pelatihan In-On-In memperoleh hasil belajar diklat pengenalan dan pemanfaatan TIK lebih tinggi daripada hasil belajar strategi pelatihan In Service Learning di PPPPTK bidang Bangunan dan Listrik Medan. Dari hasil perhitungan dapat diketahui tingginya perbandingan hasil nilai tersebut diperlihatkan oleh nilai rata-rata hasil belajar diklat pengenalan dan pemanfaatan TIK yang dilatihan dengan menggunakan strategi In-OnIn memperoleh nilai rata-rata 37,30 sedangkan nilai rata-rata hasil belajar diklat pengenalan dan pemanfaatan TIK yang dilatihan dengan menggunakan strategi in service learning memperoleh nilai rata-rata 37,30.

Kedua, Tipe kepribadian introvert memperoleh hasil belajar diklat pengenalan dan pemanfaatan TIK lebih tinggi daripada hasil belajar tipe kerpibadian extrovert di PPPPTK bidang Bangunan dan Listrik Medan. Dari hasil perhitungan dapat diketahui tingginya perbandingan hasil nilai tersebut diperlihatkan oleh nilai rata-rata hasil belajar diklat pengenalan dan pemanfaatan TIK bagi tipe kepribadian Introvert memperoleh nilai ratarata 37,90 sedangkan nilai rata-rata hasil belajar diklat pengenalan dan pemanfaatan TIK bagi tipe kepribadian memperoleh nilai rata-rata 31,40

Ketiga, Terdapat interaksi antara strategi pelatihan dan tipe kepribadian dalam memberikan pengaruh terhadap hasil belajar diklat pengenalan dan pemanfaatan TIK. Adapun hasil interaksi yang dihasilkan dalam penelitian ini adalah sebagai berikut :

a. Petatar yang memiliki tipe kepribadian Introvert akan memperoleh hasil belajar diklat pengenalan dan pemanfaatan TIK yang lebih tinggi bila dilatih dengan strategi pelatihan In-On-In daripada petatar yang dilatih dengan strategi in service learning.

b. Petatar yang dilatih dengan strategi In-InOn akan memperoleh hasil belajar diklat pengenalan dan pemanfaatan TIK yang lebih tinggi bagi petatar yang memiliki tipe kepribadian Introvert daripada petatar yang memiliki tipe kepribadian Extrovert.

c. Hasil belajar diklat pengenalan dan pemanfaatan TIK yang dilatih dengan strategi pelatihan In-In-On yang memiliki tipe kepribadian Introvert lebih tinggi daripada petatar dilatih dengan strategi In Service Learning yang memiliki tipe kepribadian Extrovert.

d. Hasil belajar diklat pengenalan dan pemanfaatan TIK yang dilatih dengan strategi pelatihan In-In-On yang memiliki tipe kepribadian Extrovert berbeda dengan hasil belajar diklat petatar yang dilatih dengan strategi In Service Learning yang memiliki tipe kepribadian Introvert.

e. Petatar yang dilatih dengan strategi In-InOn yang memiliki tipe kepribadian 
Extrovert akan memperoleh hasil belajar diklat pengenalan dan pemanfaatan TIK yang lebih tinggi daripada petatar yang dilatih dengan strategi pelatihan In Service Learning yang memiliki tipe kepribadian Extorvert.

f. Petatar yang dilatih dengan strategi In Service Learning yang memiliki tipe kepribadian Introvert akan memperoleh hasil belajar diklat pengenalan dan pemanfaatan TIK yang lebih tinggi daripada petatar yang dilatih dengan strategi pelatihan In Service Learning yang memiliki tipe kepribadian Extorvert.

\section{Saran}

Dari hasil pembahasan penelitian, simpulan, dan implikasi seperti telah diuraikan di atas, maka penulis mengajukan saran sebagai berikut:

1. Bagi guru (petatar) diklat pengenalan dan pemanfaatan TIK, pada awal pembelajaran pengenalan dan pemanfatan TIK dibekali dengan penyusunan rencana kerja dan action plan berbasis flowchart, Petatar pengenalan dan pemanfaatan TIK harus mampu menuangkan ide dalam kerangka implementasi pemanfaatan TIK sesuai bidang profesionalnya.

2. Dalam upaya peningkatan hasil belajar pengenalan dna pemanfaatan TIK senantiasa melakukan strategi pelatihan berdasarkan tipe kepribadian. Memberi langkah-langkah penyelesaian masalah pembelajaran melalui interaktif yang mengajak para petatar untuk menyelesaikan masalah secara bersama-sama pada ruang komunitas yang dapat dibuat oleh widyaiswara (penatar).

3. Bagi para penyelenggara sekolah (kepala sekolah, yayasan, direktur) untuk menyediakan sarana prasarana dalam pembelajaran on the job learning seperi : laboratorium, warnet dan ruang diskusi dalam jaringan, memasyaratkan teknologi informasi dan komunikasi melalui online informasi sebagai pengganti papan pengumuman resmi sekolah. Sekolah juga disarankan untuk mengadakan kerjasama dengan jasa pelayanan internet (internet service provider) baik untuk mendukung ketersediaan jaringan komunikasi.

4. Bagi para tenaga pengajar untuk menerapkan beberapa metode pembelajaran yang bervariasi berdasarkan tipe kepribadian yang memudahkan petatar memahami isi pesan pembelajaran. Beberapa metode pembelajaran yang dapat diterapkan untuk membelajarkan Teknologi informasi dan komunikasi adalah metode belajar mandiri terpimpim, metode kolaboratif, metode ekspositori (memberikan contoh-contoh unjuk kerja), dan lain sebagainya.

5. Menyusun strategi pelatihan berdasarkan tipe kepribadian dilakukan dengan mengembangkan materi-materi bahan ajar yang berfokus pada pemanfaatan TIK secara mandiri. Pendekatan bahan ajar harus mampu merangsang para peserta diklat untuk melakukan respon secara mandiri.

6. Strategi komunikasi pelatihan bagi tipe kepribadian Introvert lebih diarahkan dalam bentuk interaktif antara penatar dan petatar, sehingga petatar dengan tipe kepribadaian Intervert senantiasa mampu mengembangkan ide-idenya sesuai dengan hasil belajar yang diperoleh dalam kelas.

Strategi komunikasi pelatihan bagi tipe kepribadian Introvert lebih diarahkan dalam bentuk kelompok diskusi terbuka, sehingga petatar dengan tipe kepribadaian Extrovert senantiasa mampu mengembangkan dan menyampaikan ide-idenya dan dibahas untuk mencapai yang terbaik.

\section{DAFTAR PUSTAKA}

Atmodiwirio Soebagio (2002). Manajemen Pelatihan. (cet. 1). Jakarta : Ardadizya Jaya.

Byrd, J \& Brown, P.L. (2003). The Innovation Equation. Building Creativity and Risk Taking in Your Organization. San Fransisco: Jossey-Bass/Pfeiffer. A Wiley Imprint. www.pfeiffer.com

Dabbagh Nada, Ritland Bannan Brenda (2005). Online Learning : Concepts. Strategies, and Appication. New Jersey : Pearson Prentice Hall

De Bono, Edward (1993). Revolusi Berpikir Edwar de Bono. (Penerjemah Sitompul Ida dan Yamani) (2007). Bandung : Mizan Pustaka.

De Jong, JPJ \& Kemp, R. (2003). Determinants of Co-workers Innovative Behaviour: An Investigation into Knowledge Intensive Service. International Journal of Innovation Management.

Departemen Pendidikan Nasional (2006). Departemen Pendidikan Nasional Tahun 
2005 - 2009 : Мenuju Pembangunan Pendidikan Nasional Jangka Panjang 2025. Jakarta : Departemen Pendidikan Nasional.

Dimyati \& Mudjiono (2006). Belajar dan Pembelajaran. Jakarta : Asdi Mahasatya

Effendi Empy dan Zhuang Hartono (2005). Elearning : Konsep dan Aplikasi (ed. 1) Yogjakarta : Andi

Ewing K., Levine J., Reinhold A., Margaret L.Y., Lowe D., Harvey G., Mohta V., Kaufeld J., Kaufeld J., Waverka P., Hill B., Musick L. (2002). The Internet AllIn-One Desk Reference for Dummies. : New York : Hungry Minds, Inc.

Fatma (2007) Dinamis, Kreatif dan Inovatif (Online)

(http://fatma1203.wordpress.com/2007/0

8/04/, diakses 16 september 2007)

Gagne, R. (1985) The Conditions of Learning (4th ed.). New York: Holt, Rinehart \& Winston. (Available at:

http://www.psy.pdx.edu/PsiCafe/KeyThe orists/Gagne.htm; dan http://www.ittheory.com/gagne1.htm)

Gay L.R. (1981). Educational Research : Competencies for Analysis \& Application. USA : A Bell \& Howell Company.

Given K. Barbara (2002). Brain-Based Teaching. (Penerjemaha Dharma H. L.) (2007). Bandung : Mizan Pustaka

Guruvalah (2006). Orientasi Baru dalam Psikologi Belajar. (Online) (http://www.guruvalah.tk, diakses 7 september 2007)

Miarso Yusufhadi (2005). Menyemai Benih Teknologi Pendidikan Jakarta : Kencana

Miller John P \& Seller Wayne (1985). Curriculum, Perspectives and Practices. USA : The Alpine Press, Inc.

Panjaitan Binsar (2006). Karakteristik Pebelajar dan Kontribusinya terhadap Hasil Belajar. Medan : Penerbit Poda

Patton Patricia (1997). Kecerdasan Emosional Pelayanan Sepenuh Hati. (Penerjemah Hermes) (1998). Jakarta : Pustaka Delapratasa.

Purbo W. Onno (1994). Pembangunan SDM berbasis Teknologi Informasi, (http://onno.vlsm.org/v09/onno-ind1/application/education/pembangunan- sdm-berbasis-teknologi-informasi,

diakses 5 september 2007)

Raka Gede (2003). Menggaris bawahi Peran Idealisme, Karakter dan Komunitas dalam Transformasi Institusi. Risalah disampaikan sebagai Pidato Ilmiah pada Sidang Terbuka Peringatan Dies Natalis ke 44 Institut Teknologi Bandung pada tanggal 2 Maret 2003.

Rosenberg, J.M., (2001). E-learning: Strategies for delevering knowledge in the digital age. USA : McGraw-Hill.

Riduan. (2006). Belajar Mudah Penelitian untuk Guru, Karyawan dan Peneliti Pemula. (cet. 3). Bandung: Alfabeta

Rusman : Konsep Dasar Teknologi Informasi dan Komunikasi, Perkembangan dan Pemanfaatan Komputer (Materi pembelajaran online) unit 1 dan 2 (www.umm.ac.id/pjj/file.php/1/moddata/ forum/1/15/, diakses 7 September 2007)

Salisbury David F. (1996). Five Technologies for Educational Change : system thinking, systems design, quality science, change management, instructional technology. USA : Englewood Cliffs, New Jersey

Seels B. Barbara \& Richey C. Rita (1994). Instructional Technology: The Definition and Domains of the Field. (Penerjemah Prawiradilangit D., Raharjo R., dan Miarso Y.) Jakarta : Unit Percetakan Universitas Negeri Jakarta.

Suit Yusuf \& Almasdi. (2006). Aspek Sikap Mental dalam Manajemen Sumber Daya Manusia (Ed. 3). Bogor : Penerbit Ghalia Indonesia

Surya Muhamad (2006). Potensi Teknologi Informasi dan Komunikasi dalam Peningkatan Mutu Pembelajaran di Kelas, (www.edukasi.net/artikel diakses 5 September 2006)

Tippelt Rudolf and Amorós Antonio. (2003). Pendidikan Kejuruan Berbasis Kompetensi, Kumpulan Materi : Pembelajaran bagi Para Pembelajar. Germany : InWent - Capacity Building Internasional.

Tippelt Rudolf and Amorós Antonio. (2003). The project method in Vocational Training. Germany : InWent - Capacity Building Internasional. 